Rapp. Grønlands geol. Unders. 58, 7-15 (1973)

\title{
PRELIMINARY RESULTS OF THE MAPPING IN THE MIGMATITE COMPLEX AROUND FØNFJORD AND GÅSEFJORD, SCORESBY SUND
}

\author{
Niels Henriksen and A. K. Higgins
}

\section{Introduction}

The Geological Survey of Greenland (GGU) carried out in 1972 the fifth summer of systematic mapping in the crystalline complex of the Scoresby Sund region. The region mapped in the southernmost part of the inner fjord zone was an extension of that mapped during the first three summers. The main geological divisions in the region have been outlined by Henriksen \& Higgins $(1969,1970,1971)$.

The crystalline complex in the inner fjord region of Scoresby Sund can be divided into a western gneiss and schist zone and an eastern zone of migmatites and associated plutonic rocks. A major approximately $\mathrm{N}-\mathrm{S}$ trending, east dipping thrust zone following Rødefjord separates these two units. The western zone is described by Phillips, Stillman, Friderichsen \& Jemelin (this report) and this account only deals with the eastern migmatite zone.

The migmatite zone was in 1972 mapped by K. Bucher-Nurminen, Zürich; J. Escher, Copenhagen; M. Fumasoli, Altdorf; N. Henriksen, Copenhagen; A. K. Higgins, Copenhagen and G. Sawatzki, Geneva. Each geologist mapped about 500$600 \mathrm{~km}^{2}$ in a field season of about 7 weeks. The areas mapped by each geologist are shown on the key of the geological map (map 1). As in previous years topographical maps at a 1:50 000 scale, enlarged from 1:200 000 originals, were used for compilation of geological results and extensive use was made of oblique and vertical aerial photographs.

This report is based on information supplied by all the geologists participating in the mapping, many of whom in due course will present more detailed accounts of their individual areas. The writers are responsible for the interpretations presented which do not necessarily coincide exactly with those of their colleagues.

\section{Previous investigations and general geology}

The crystalline areas on southern Milne Land and on Gåseland between Fønfjord and Gåsefjord have not previously been systematically mapped, and only scattered previous observations were available. Bay (1895) published the first 
rough sketch map of the region and gave a short description of rocks on Danmark $\emptyset$. H. G. Backlund and E. Wenk visited the area in 1933 (Backlund, 1955) and Haller (1971) compiled previous information with his own reconnaissance observations from the Scoresby Sund region.

The results of GGU's mapping of the crystalline areas in the inner Scoresby Sund region have been outlined by Henriksen \& Higgins $(1969,1970,1971)$. More detailed accounts are available for Bjørneøer (Kalsbeek, 1969), south-east Renland (Chadwick, 1971) and Stor $\varnothing$ (Olesen \& Sørensen, 1972).

The migmatite zone in the Scoresby Sund region forms a central N-S trending unit, which is approximately $90 \mathrm{~km}$ wide and can be traced more than 200 kilometres from south to north. To the west it is separated from the western gneiss and schist zone by an east dipping thrust zone and to the east a major fault forms the boundary to the post-Caledonian sediments. Tertiary plateau basalts overlie the crystalline rocks in the southern part of the Scoresby Sund region.

A thick supracrustal sequence of interbanded quartzites and mica schists, massive mica schists and siliceous gneisses occurs folded together with a gneissic basement complex in the gneiss and schist zone and this has been termed the Krummedal supracrustal sequence. Areas of Krummedal sequence rocks at the western margin of the migmatite zone show a continuous transition eastwards into migmatites. Extensive sheets of garnet augen granite occur in the migmatites on Renland and northern Milne Land and these sheets and the migmatites are influenced by a major isoclinal recumbent folding. Kalsbeek (1969) on Bjørneøer and Chadwick (1971) on Renland distinguish two phases of migmatisation separated by intrusions of sheets of monzonitic/dioritic rocks. Late to post-kinematic granites (sensu lato) especially concentrated in the northern part of the migmatite zone in the Stauning Alper are the youngest of the plutonic rocks. The easternmost part of Milne Land is formed by a separate fault block comprising a sequence of metasediments and a series of post-kinematic intrusions of granodioritic, quartz syenitic and granitic rocks.

Isotopic age determinations on rocks from the migmatite zone indicate that the augen granites were intruded or recrystallised at least $950 \mathrm{~m}$. y. ago (zircon age by Steiger \& Henriksen, 1972). The homogeneous granitic rocks from the Stauning Alper have given a spread of $\mathrm{Rb} / \mathrm{Sr}$ mineral ages from $c .1150 \mathrm{~m}$. y. to $c .450 \mathrm{~m}$. y. (Hansen \& Steiger, 1971; Hansen, Steiger \& Henriksen, 1972) indicating that at least some of the granites are pre-Caledonian intrusives which have suffered a Caledonian imprint. Age determinations on zircons and monazites from the migmatites on Bjørneøer reveal a pre-Caledonian history as well as a Caledonian event (Oberli \& Steiger, this report). The intrusive complex in the east Milne Land fault block has given $\mathrm{Rb} / \mathrm{Sr}$ mineral ages of 1490 and $1315 \mathrm{~m}$. $\mathrm{y}$. indicating the minimum age for these intrusions. The latest pegmatites in the Stauning Alper gave $c$. $380 \mathrm{~m} . \mathrm{y}$.

The cumulative evidence from the isotopic age determinations seems to indicate 
that the migmatite zone with its plutonic rocks attained its main characteristics during a Precambrian orogenic event, and was partially reactivated during the Caledonian orogeny.

\section{Geological divisions}

The migmatite zone in southern Milne Land, on Gåseland and south of Gåsefjord comprises gneissic and granitic migmatites with scattered bands of metasediments and various intrusive, mostly sheet-formed, granites (sensu lato). The main part of the migmatites are characterised by a paleosome of quartzitic and gneissic material, but in some units agmatitic amphibolitic enclaves occur abundantly in the migmatite. A sequence of siliceous gneisses which is only weakly migmatised is found in western Gåseland. Foliated hornblende-biotite quartz-diorites are found in sheet-formed intrusions around Danmark $\emptyset$ and on the south coast of Gåseland. Post-kinematic plutonic intrusions belonging to the east Milne Land fault block are exposed on the north-eastern extremity of the area mapped.

\section{Metasedimentary bands and enclaves in the migmatites}

Bands and enclaves of metasedimentary rocks are widespread in the migmatites on Gåseland, and often form mappable units. The bands are up to several hundred metres thick and comprise an interbanded sequence of biotite-garnet-sillimanite gneisses, quartzites, quartzitic gneisses, marbles, calcareous schists and occasional amphibolite and garnet-amphibolite bands. The marbles, which are the most distinctive of these rocks, form up to $10-20 \mathrm{~m}$ thick bands, and can often be used as marker horizons. They are whitish to light grey rocks in which siliceous marble layers are interbanded with nearly pure, often coarse-grained marble layers. Isoclinal minor folds with axial planes conformable to the general orientation of the surrounding rocks are common in the marbles.

Slightly or non-migmatised supracrustal rocks occur in synformal cores surrounded by migmatites in the south-western part of Milne Land. These supracrustals comprise banded, fine-grained, biotite-garnet-sillimanite gneisses with occasional bands of amphibolite, quartzite and siliceous gneiss. There are also thin horizons of white marbles.

Isolated boudins and remnants of metasedimentary rocks may be encountered in the migmatites on Gasseland and south-western Milne Land, but they are only found as paleosome 'schollen' in the migmatites of the central and eastern part of Milne Land mapped in 1972.

\section{Banded siliceous biotite gneisses}

In the north-westernmost part of the migmatite zone on Gåseland there occurs 
a few kilometre thick sequence of well banded, dark grey siliceous biotite gneisses, biotite quartzites and biotite schists. Garnet is only found occasionally and sillimanite has not yet been observed. The rocks are only slightly migmatised but they are cut by a series of metre-wide pegmatitic veins and dykes.

The siliceous biotite gneisses occupy a major open synform with a steep axial plane. There are gradual transitions between these gneisses and the surrounding migmatites, and the paleosome in the adjacent migmatites is the same rock type as found in the slightly migmatised core of the synform.

\section{Migmatitic gneisses and granites}

The main part of the mapped region is formed by rusty brown migmatitic gneisses and migmatitic granites. There exists a complete gradational transition between these two rock types, the difference being only the relative proportion of paleosome and neosome. Generally rocks with more than half of the bulk formed by neosome and with a homogeneous structure on a mesoscopic scale have been mapped as migmatite granite.

There exists an overall increase in migmatisation intensity towards the northeast. South of Gåsefjord and on Gaseland the migmatites are often of a well banded gneissic character, whereas these on eastern Milne Land are more granitic and homogeneous. In Milne Land extensive granitic areas surrounded by more gneissic migmatites occur. The migmatite granites contain numerous gneissic enclaves and schlieren.

The rusty brown gneissic migmatites have a paleosome of siliceous biotitic-garnet-sillimanite gneiss and quartzitic biotite-garnet gneiss. Only few amphibolitic paleosome enclaves occur. The neosome is formed by a leucocratic fine- to medium-grained garnet-biotite granite. The structure varies between regular banded and veined types and irregular types with abundant 'schollen'.

A large scale flat-lying banding has been observed in the migmatites in the central and eastern part of the mapped region. This banding can be observed on steep mountain slopes, in coast profiles and in valleys, which often expose a relief of more than 1500 metres. The lower parts of these sections often comprise banded migmatitic gneisses whereas the higher parts are formed by migmatitic granites sensu lato with gneissic schlieren and bands. In some cases these granites may be regular sheet-formed bodies with intrusive relationships to the surrounding migmatites. The large scale banding could be explained either by assuming a plutonic concentration of granitic material at a high level above the banded migmatites, or by early tectonic emplacement of sheets of migmatitic granite above the lower gneissic units.

A distinct type of migmatite with abundant amphibolite inclusions is found in a large area on the western part of Milne Land; such rocks occur only occasionally elsewhere in small areas in the migmatite zone. In addition to the amphibolites, fine-grained, siliceous, biotite gneisses are found and in one type inclusions of 
banded biotite gneisses and rusty calcareous gneisses are represented in the paleosome. The agmatitic amphibolitic enclaves may be up to 10 metres in length. The neosome here is fine-grained, granitic and generally without garnet, which is in contrast to the normal neosome of the rusty brown gneissic migmatites.

There are lithological similarities between the agmatitic amphibolitic migmatites and the amphibolitic banded basement rocks in the 'gneiss and schist zone' which could indicate that they have a common origin.

\section{Granites (sensu lato)}

Various massive granitic rocks occur throughout the migmatite area as sheets or in irregular shaped bodies. These granites are intimately related to the migmatites. In many cases it is possible to show that the sheet-formed bodies in particular have cross-cutting relations to the surrounding migmatites, but there are also many examples of completely gradational transitions from homogeneous granite via a schollen or schlieren zone into gneissic migmatites.

The largest concentration of granites is found in south-western Milne Land. Here various types of porphyroblastic biotite granites (without garnets), biotite bearing aplite granite and medium- to coarse-grained, garnet-biotite-K-feldspar granites occur. There are gradual transitions between the porphyroblastic granite and the adjacent migmatitic gneisses. Aplite granite material, forming the neosome of migmatite granites with abundant inclusions in this area, may also form more homogeneous intrusive bodies. The medium- to coarse-grained, garnet-bearing granites form thick, flat-lying sheets above the rusty brown migmatitic gneisses. The granite sheets contain occasional conformable gneissic schlieren and locally may be somewhat foliated.

In the eastern part of Milne Land and on Gasseland the massive granites are mainly found as thin conformable sheets in the migmatites. Most are flat-lying, leucocratic, biotite-garnet granites which may or may not have sharp boundaries to the adjacent migmatites. The granitic material is identical to that forming the neosome phase in the migmatite granites and all transitions between these two granite forms exist. Feldspar porphyroblasts are common.

In the eastern part of Gaseland a few sheets of gneissic augen granites traceable for several kilometres and of similar type to those reported from Renland occur (Chadwick, 1971). They are conformable with the migmatitic host rock and internally may exhibit minor folding.

\section{Biotite-hornblende quartz diorite}

Around Danmark $\emptyset$ and at the coast of southern Gåseland there occur major sheet-formed bodies of biotite-hornblende quartz diorite. The sheets are in places more than 500 metres thick. They are conformable with the structure in the adjacent migmatites and are also often foliated, especially in the marginal zones. The lower boundary of the sheet at Danmark $\emptyset$ is a thrust, but in other places the 
boundary indicates an intrusive emplacement. Along the upper and lower boundary of the sheet in southern Gasseland there occur marble lenses and bands which apparently originally formed a continuous horizon which was the site of emplacement of the quartz diorite. Major xenoliths of irregular shaped bodies of marble occur in the central part of this sheet. Smaller xenoliths occur especially in the marginal zones of both quartz diorite sheets. On Danmark $\emptyset$ a large wedge-formed gneiss and migmatite layer is found in the quartz diorite.

The quartz diorite is a dark greenish grey, medium-grained rock. Biotite and hornblende are the usual mafic minerals, but some rocks also contain pyroxene. Numerous small rounded inclusions of mafic diorite sensu lato may be cogenetic with their host rock. The quartz diorite is cut throughout by abundant pale pink coloured biotite pegmatites up to $20-30 \mathrm{~cm}$ wide, which transect the bodies irregularly.

There is no conclusive evidence for the relative age of emplacement of the quartz diorites. They are apparently younger than the regional main migmatisation and deformation, but are even so slightly metamorphosed and slightly deformed.

\section{Structures}

There exist only few good marker horizons in the part of the migmatite zone mapped in 1972 and it has therefore not been easy to gain a clear picture of the structures. Only a limited number of mesoscopic and megascopic fold closures have been observed, although it is possible that others exist but have been overlooked due to the uniform lithology of many of the migmatites. The earliest recognisable deformation is reflected by small pre-migmatitic intrafolial folds in the gneissic paleosome. The main structures in the mapped region are approximately $\mathrm{E}-\mathrm{W}$ trending and comprise early recumbent and tight folds which deformed some of the granitic sheets in the migmatites, and more open megascopic east-west structures, with vertical or very steeply inclined axial planes. Fold axes in general have gentle easterly plunges. The minor structures are generally conformable with the megascopic folds. Throughout the region a general east-west trending lineation is visible.

In some parts of the area late megascopic N-S to NNW-SSE trending open antiforms and synforms have been found. In the western part of the region some $\mathrm{N}-\mathrm{S}$ structures are apparently related to normal faults and may be drag features.

An important major thrust zone separates the western gneiss and schist zone from the eastern zone of migmatites. This thrust zone cuts across the western part of Gåseland with an approximately N-S trend and has a dip of $15-45^{\circ}$ towards the east. The northwards continuation of the thrust follows the west side of Rødefjord. On Gåseland the thrust zone comprises a $20-50 \mathrm{~m}$ wide strongly mylonitised and 
crushed zone, and in places it is composite and formed of several thrust wedges. The thrust plane is more or less conformable with the main structure in the mica schists to the west, but is often discordant to the structures in the eastern migmatites. The contrast between the kyanite-bearing schist zone to the west and the zone of sillimanite-bearing migmatites implies a juxtaposition along the thrust of two units formerly more widely separated.

A series of approximately north-south trending faults are concentrated in the western and eastern parts of the migmatite zone. Many of these have a vertical component of displacement and probably form the southward extension of the fault sets described from Renland (Chadwick, 1971).

\section{Conclusions}

The results of the 1972 mapping fit in generally very well with the 1969 and 1970 mapping in the migmatite zone and only a few general comments are necessary.

Migmatitic gneisses and migmatite granites are again the dominant rock types, but in Gåseland and the outcrops further south there are indications of a fall-off in migmatitic intensity southwards. The metasedimentary paleosome inclusions and the larger areas of non-migmatitic metasediments still have lithological characteristics comparable with those of the Krummedal supracrustal sequence in the neighbouring zone, and there is a noticeable proportion of amphibolite in the paleosome in these southern migmatite areas as well as in the Krummedal sequence of the southern part of the gneiss and schist zone.

It is possible that the distinctive amphibolite-rich migmatites of extreme southwest Milne Land may be equivalent to the basement gneiss complexes underlying the Krummedal sequence in the gneiss and schist zone. There are a few other areas of possibly the same origin, but relationships are obscured by deformation and migmatisation and it is difficult to be certain.

Sillimanite is conspicuous throughout most of the area mapped and frequently forms a strong E-W lineation. Cordierite has been reported from eastern parts of the mapped area, and indeed seems to be a feature of an eastern strip of the migmatite zone as a whole.

The main deformation phases again seem intimately related with development of the migmatites and emplacement of some of the granitic bodies, but there are also a number of late megascopic structures. A number of faults and the major thrust at the west margin of the zone appear to be the latest structural events.

While in the first accounts of the new mapping (Henriksen \& Higgins, 1969, 1970, 1971; Olesen \& Sørensen, 1972; Kalsbeek, 1969; Chadwick, 1971) it had been assumed that the deformation, metamorphism, migmatisation and plutonism 
of the migmatite zone were all essentially part of the Caledonian orogenesis, much in line with the traditional viewpoint (Haller, 1971), the variety of pre-Caledonian and Caledonian age dates from the zone outlined earlier point to a very different and rather complex picture. The three-point isochron on the Krummedal sequence schists (Hansen et al., this report) suggests a metamorphic age of c. $1200 \mathrm{~m}$. y., and makes any correlation of this with the late Precambrian Eleonore Bay Group seem very unlikely.

Among the workers who have mapped various parts of the migmatite zone there is now a diversity of opinion as to the genesis of the region. If the metasediments within the zone are part of the Krummedal sequence as has always been assumed then these too are early Proterozoic and not Caledonian geosynclinal sediments. There are some who suggest the peak of orogenic activity in the migmatite zone corresponds to the metamorphic date of $c .1200 \mathrm{~m}$. y. in the gneiss and schist zone, and that Caledonian activity was somewhat superficial (cf. Philips et al., this report). Other workers point to the many undoubted Caledonian ages on plutonic bodies as evidence of significant Caledonian activity, and view older ages as due to contamination. Further isotopic work is necessary before any firm conclusions can be made.

It is an obvious line of thought to question whether the central metamorphic complex of the region immediately north of $72^{\circ}$ has a similar genesis to that of the Scoresby Sund region. There is a possibility that some of the metasedimentary zones may be equivalents of the Krummedal supracrustal sequence, and that some of the migmatitic and plutonic activity generally attributed to the Caledonian orogeny (Haller, 1971) may be pre-Caledonian. However, this is pure speculation which only new field investigations supported by isotopic studies will resolve.

\section{References}

[Backlund, H. G.] 1955: Helge Backlund's travels. In Koch, L. Report on the expedition to central East Greenland 1926-39. Conducted by Lauge Koch. Part II. Meddr Grønland 143 (2), 303-361.

Bay, E. 1895: Geologi. In Ryder, C. Den østgrønlandske Ekspedition, udf $\varnothing$ rt i Aarene 1891-92 under Ledelse af C. Ryder. Meddr Grønland 19, 145-187.

Chadwick, B. 1971: Preliminary account of the geology of south-east Renland, Scoresby Sund, East Greenland. Rapp. Gronlands geol. Unders. 34, 32 pp.

Haller, J. 1971: Geology of the East Greenland Caledonides. Interscience Publishers, New York, 413 pp.

Hansen, B. T. \& Steiger, R. H. 1971: The geochronology of the Scoresby Sund area. Progress report 1: $\mathrm{Rb} / \mathrm{Sr}$ mineral ages. Rapp. Gronlands geol. Unders. 37, 55-57.

Hansen, B. T., Steiger, R. H. \& Henriksen, N. 1972: The geochronology of the Scoresby Sund area. Progress report 2: $\mathrm{Rb} / \mathrm{Sr}$ mineral ages. Rapp. Grønlands geol. Unders. 48, 105-107.

Henriksen, N. \& Higgins, A. K. 1969: Preliminary results of mapping in the crystalline 
complex around Nordvestfjord, Scoresby Sund, East Greenland. Rapp. Grønlands geol. Unders. 21, 5-20.

Henriksen, N. \& Higgins, A.K. 1970: Preliminary results of mapping in the crystalline complex of Renland, the southern Stauning Alper and south-west Liverpool Land, Scoresby Sund, East Greenland. Rapp. Gronlands geol. Unders. 30, 5-17.

Henriksen, N. \& Higgins, A. K. 1971: Preliminary results of mapping in the crystalline complex around Rypefjord and Rødefjord, and on northern Milne Land, Scoresby Sund, East Greenland. Rapp. Gronlands geol. Unders. 37, 5-18.

Kalsbeek, F. 1969: Preliminary report on the geology of Bjørneøer, Scoresby Sund. Rapp. Gronlands geol. Unders. 26, 33 pp.

Olesen, N. Ø. \& Sørensen, K. 1972: Caledonian fold- and fabric-elements: a model. Proc. 24th int. geol. Congr., Canada 3, 533-544.

Steiger, R. H. \& Henriksen, N. 1972: The geochronology of the Scoresby Sund area. Progress report 3: Zircon ages. Rapp. Gronlands geol. Unders. 48, 109-114. 